\title{
Hypophosphatemic vitamin D resistant rickets in an adult: A rare case report
}

\author{
Vidiyala Harika ${ }^{1}$, Abhilash Mishra ${ }^{2}$, Sourya Acharya ${ }^{3, *}$, Samarth Shukla ${ }^{4}$ \\ ${ }^{1,2}$ Resident, ${ }^{3,4}$ Professor, ${ }^{1,2,3}$ Dept. of Internal Medicine, ${ }^{4}$ Department of Pathology, Acharya Vinoba Bhave Rural \\ Hospital and Jawaharlal Nehru Medical College, DMIMS University, Wardha, Maharashtra, India
}

\section{*Corresponding author:}

Email: souryaacharya74@gmail.com

\begin{abstract}
Hypophosphatemic Vitamin D resistant rickets is a rare disease, which is characterized by lack response to vitamin D at the level of receptors leading to rickets. It is also associated with disturbed metabolism and activity of vitamin $\mathrm{D}$ and/or disturbed phosphate metabolism. We present a case of a 19 year old male presented with symptoms and signs of Vitamin D deficiency and diagnosed as Vitamin D resistant rickets.
\end{abstract}

Keywords: Vitamin D, Phosphate, Rickets.

Received: $13^{\text {th }}$ November, 2017

\section{Introduction}

Hypophosphatemic Vitamin D resistant rickets is a condition characterized by, features of rickets that is resistant to normal therapeutic doses of vitamin $\mathrm{D}$. the treatment usually requires high doses of vitamin $\mathrm{D}$. This rare condition was first described by Albright, Butler and Boon berg in 1927. ${ }^{1}$

For normal calcium homeostasis, calcitriol or 1, 25-dihydroxy cholecalciferol, the active form of vitamin $\mathrm{D}$ is crucial. Vitamin D receptors play an important role for down regulation of calcitriol on the target tissues. This rare autosomal recessive genetic disease in humans, is caused by heterogeneous mutations in vitamin D receptor gene. The cardinal clinical presentation is characterized by features of rickets along with typical biochemical abnormalities in form of, hypocalcaemia, elevated serum calcitriol, and secondary hyper parathyroidism. Some patients can present with associated dermatological abnormalities like alopecia and dermal cyst. ${ }^{2-5}$

\section{Case Report}

A 19 year old male presented to us with complains of back pain, groin pain and lower limb weakness since 3 years duration. The pain was intermittent and dull aching type. The lower limb weakness was gradual in onset aggravated by exercise and relieved slightly on rest. There was no history of fever, night sweats, morning stiffness, small joints swelling, paresthesias and urinary incontinence. On examination vitals were stable mild pallor was present systemic examination was normal. Musculoskeletal examination revealed short stature, bowed legs and scoliosis. (Fig. 1, 2)

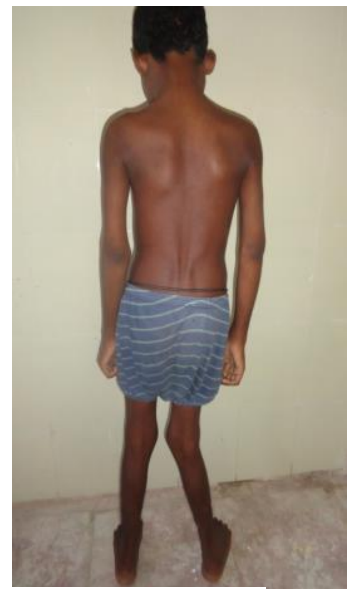

Fig. 1: Showing short stature

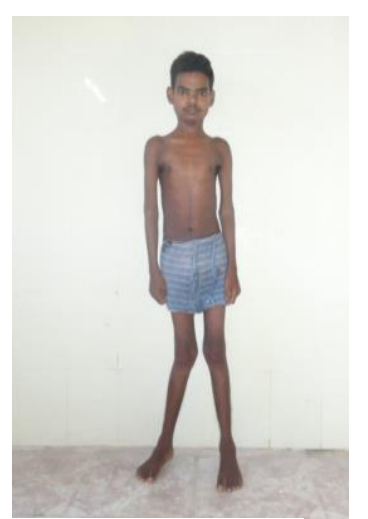

Fig. 2: Scoliosis and Bowed legs

Investigations revealed, Normal complete blood counts. KFT, LFT was normal. X ray 
thoraco-lumbar spine revealed looser zones, decreased mineralization, reduced disc spaces. (Fig. 3) Serum calcium $6.4 \mathrm{mg} / \mathrm{dl}$, alkaline phosphatase was $1100 \mathrm{IU}$, Parathyroid hormone: $865.5 \mathrm{pg} / \mathrm{Ml}$, serum inorganic phosphate: $1.4 \mathrm{mg} \%$, whereas the values of $1,25-$ dihydroxyvitamin $\mathrm{D}$ was high $(185 \mu \mathrm{mol} / \mathrm{L})$, suggesting end organ resistance to vitamin $\mathrm{D}$.

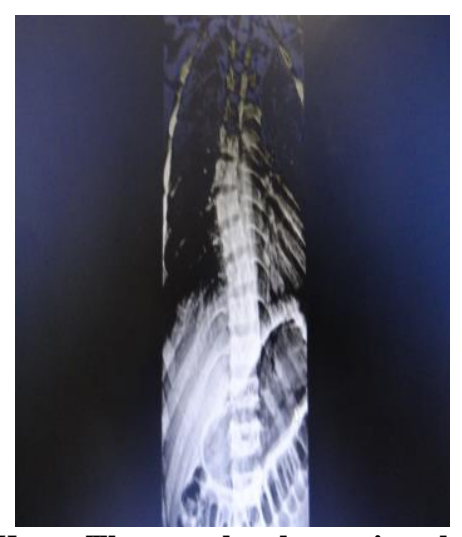

Fig. 3: $\mathrm{X}$ ray Thoraco-lumbar spine showing looser zones, decreased mineralization, reduced disc spaces, and scoliosis

The patient was treated with Vitamin D $50,000 \mathrm{IU} /$ week for 8 weeks with tablet sodium and potassium phosphate $250 \mathrm{mg}$ twice a day.

\section{Discussion}

Hypophosphatemic rickets is a rare autosomal recessive disorder. It usually manifests in pediatric age group. There is no established guidelines regarding indications of treatment of this disease in adult patients. The aim of the therapy is to decrease the pain, which usually occur because of microfractures and/or osteomalacia of bones. All symptomatic cases should receive treatment. ${ }^{6-7}$ Surgical interventions like corrective osteotomy, may be planned to be temporarily promote bone mineralization. ${ }^{6}$

The conventional treatment is based on oral phosphate salts, usually given twice daily, and active vitamin D metabolites. ${ }^{8}$ The goal of management is to improve the symptoms, and not to normalize serum phosphate levels. Careful monitoring of plasma calcium, $\mathrm{PTH}$, creatinine, and 24-h urinary calcium excretion is required. Overtreatment usually leads to tertiary hyperparathyroidism, hypercalciuria with nephrocalcinosis and renal insufficiency, resulting from excess calcitriol., ${ }^{9,10}$ Tertiary hyperparathyroidism responds to adjunctive therapy by 1,25 -dihydroxyvitamin $\mathrm{D}$, even if surgery is the likely modality of management. ${ }^{11}$

\section{References}

1. Levine BS, Kleeman CR, Felsenfeld AJ. The journey from vitamin D-resistant rickets to the regulation of renal phosphate transport. Clin J Am Soc Nephrol. 2009 Nov;4(11):1866-77. doi: 10.2215/CJN.03000509.

2. Malloy PJ, Pike JW, Feldman D. Hereditary 1,25dihydroxyvitamin D-resistant rickets. In: Feldman D, Glorieux F, Pike JW, editors. Vitamin D. Second Edition. San Diego, CA: Elsevier; 2005. pp. 1207-1238.

3. Feldman D, Malloy PJ, Krishnan AV, Balint E. Vitamin D: biology, action and clinical implications. In: Marcus R, Feldman D, Nelson DA, Rosen CJ, editors. Osteoporosis. Vol. 3. San Diego: Academic press;2007. pp.317-82.

4. Pliskin ME, Brown AM, Baden EE, Kimball HG. Vitamin D resistant rickets of a young adult patient. A review and case report $1975 \mathrm{Jul}-$ Sep;30(3):77-80.

5. Fadavi S, Rowold E..Familial hypophosphatemic vitamin D-resistant rickets: review of the literature and report of case. ASDC J Dent Child. 1990 May-Jun;57(3):212-5.

6. Carpenter TO, Imel EA, Holm IA, Jan de Beur S.M, Insogna K.L. A clinician's guide to X-linked hypophosphatemia. Journal of Bone and Mineral Research. 2011;26:1381-8.

7. Sullivan W, Carpenter T, Glorieux F, Travers R, Insogna $\mathrm{K}$. A prospective trial of phosphate and 1,25-dihydroxyvitamin D3 therapy in symptomatic adults with $\mathrm{X}$-linked hypophosphatemic rickets. Journal of Clinical Endocrinology and Metabolism. 1992;75:87985. doi:10.1210/jcem.75.3.1517380

8. Imel EA, DiMeglio LA, Hui SL, Carpenter TO, Econs MJ. Treatment of X-linked hypophosphatemia with calcitriol and phosphate increases circulating fibroblast growth factor 23 concentrations. Journal of Clinical Endocrinology and Metabolism. 1850;95:18466.doi:10.1210/jc.2009-1671

9. Rivkees SA, el-Hajj-Fuleihan G, Brown EM, Crawford JD. Tertiary hyperparathyroidism during high phosphate therapy of familial hypophosphatemic rickets. Journal of Clinical Endocrinology and Metabolism. 1992;75:1514 8. doi:10.1210/jcem.75.6.1464657

10. Taylor A, Sherman NH, Norman ME. Nephrocalcinosis in X-linked hypophosphatemia: effect of treatment versus disease. Pediatric Nephrology. 1995;9:1735.doi:10.1007/BF00860736

11. Carpenter TO, Keller M, Schwartz D, Mitnick M, Smith C, Ellison A, Carey D, Comite F, Horst R, Travers R, et al. 25 Dihydroxyvitamin D supplementation corrects hyperparathyroidism and improves skeletal abnormalities in X-linked hypophosphatemic rickets - a clinical research center study. Journal of Clinical Endocrinology and Metabolism.1996;81:23818. doi:10.1210/jcem.81.6.8964881 